\title{
PENYAKIT IBU TERHADAP KEJADIAN ABORTUS IMMINENS DI RUMAH SAKIT UMUM DAERAH KOTA PADANGSIDIMPUAN
}

\author{
Layla Fadhilah Rangkuti ${ }^{1}$, Sri Rahayu Sanusi², Delfi Lutan ${ }^{3}$
}

\author{
${ }^{1}$ Mahasiswa Program Studi S2 Ilmu Kesehatan Masyarakat, Fakultas Kesehatan Masyarakat, Universitas Sumatera Utara \\ Email: ilah.fadhilah17@gmail.com \\ ${ }^{2}$ Dosen Fakultas Kesehatan Masyarakat, Universitas Sumatera Utara \\ Email:ayusans@yahoo.com \\ ${ }^{3}$ Dosen Fakultas Kedokteran, Universitas Sumatera Utara
}

\begin{abstract}
ABSTRAK
Abortus imminens adalah abortus tingkat permulaan dan merupakan ancaman terjadinya abortus, ditandai dengan perdarahan pervaginam, ostium uteri masih tertutup dan hasil konsepsi masih baik dalam kandungan. Rata-rata terjadi 114 kasus abortus per jam. Sebagian besar studi menyatakan kejadian abortus antara 15-20\% dari semua kehamilan. Kalau dikaji lebih jauh kejadian abortus sebenarnya bisa mendekati 50\%. Komplikasi abortus imminens berupa perdarahan atau infeksi yang dapat menyebabkan kematian. Tujuan penelitian ini adalah untuk menganalisis Hubungan Penyakit Ibu Dengan Kejadian Abortus Imminens di Rumah Sakit Umum Daerah Kota Padangsidimpuan. Jenis penelitian ini bersifat studi analitik observasional dengan desain penelitian case control. Pengumpulan data dilakukan dengan melihat status rekam medik pasien yang mengalami abortus imminens. Sampel kasus dan kontrol dalam penelitian ini berjumlah 100 dengan kriteria inklusi dan ekslusi yang telah ditetapkan. Metode analisis data yang digunakan meliputi analisis univariat dan analisis bivariat dengan chi-square. Berdasarkan hasil penelitian menunjukkan terdapat pengaruh penyakit ibu ( $\mathrm{p}=0,0001) \mathrm{OR}=26,0$ (95\% CI 8,79$76,8)$ dengan kejadian abortus imminens. Disimpulkan bahwa ibu hamil yang memiliki penyakit mempunyai risiko 26 kali akan menderita abortus imminens dibandingkan dengan ibu hamil yang tidak memiliki penyakit.
\end{abstract}

Kata Kunci: Ibu Hamil; Abortus Imminens; Penyakit Ibu

\section{ABSTRACT}

Imminent abortion is an initial abortion and is a threat to abortion, characterized by vaginal bleeding, uterine ostium is still closed and the conception is still good in the womb. An average of 114 cases occur abortion per hour. Most studies state the incidence of abortion between 15-20\% of all pregnancies. If examined further the actual incidence of abortion can be close to 50\%. Complications of imminent abortion in the form of bleeding or infection that can cause death. The purpose of this study was to analyze the Relationship between Mother's Disease and the Imminent Abortion in the Regional General Hospital of Padangsidimpuan. This type of research is observational analytic study with case control research design. Data collection was carried out by looking at the medical record status of patients experiencing abortion imminens. Case and control samples in this study were 100 with inclusion and exclusion criteria that have been set. Data analysis methods used include univariate analysis and bivariate analysis with chi-square. Based on the results of the study showed there is an influence of maternal disease ( $p=$ 0.0001) $O R=26.0$ (95\% CI 8.79 - 76.8) with the incidence of imminent abortion. It was concluded that pregnant women who have the disease have a risk of 26 times will suffer from abortion imminens compared with pregnant women who do not have the disease.

Keywords: Pregnant Women; Imminent Abortion; Maternal Disease 


\section{PENDAHULUAN \\ Latar Belakang}

Menurut World Health Organization (WHO), lima penyebab kematian ibu terbesar yaitu perdarahan, hipertensi dalam kehamilan, infeksi, partus lama/macet, dan abortus. Kematian ibu di Indonesia masih di dominasi oleh tiga penyebab utama kematian yaitu perdarahan, hipertensi dalam kehamilan, dan infeksi (Kurniawan, 2016). Abortus Imminens adalah terjadinya perdarahan bercak yang menunjukan ancaman terhadap kelangsungan suatu kehamilan. Dalam kondisi seperti ini kehamilan masih mungkin berlanjut atau dipertahankan, ditandai dengan perdarahan bercak hingga sedang, serviks tertutup (karena pada saat pemeriksaan dalam belum ada pembukaan), uterus sesuai usia gestasi, kram perut bawah, nyeri memilin karena kontraksi tidak ada atau sedikit sekali, tidak ditemukan kelainan pada serviks (Rukiyah, 2010).

Rata-rata terjadi 114 kasus abortus per jam. Sebagian besar studi menyatakan kejadian abortus antara 15-20 \% dari semua kehamilan. Kalau dikaji lebih jauh kejadian abortus sebenarnya bisa mendekati 50\%. Hal ini dikarenakan tingginya angka chemical pregnancy loss yang tidak diketahui pada 2-4 minggu setelah konsepsi. Sebagian besar kegagalan kehamilan ini dikarenakan kegagalan gamet, misalnya sperma dan disfungsi oosit (Prawirohardjo, 2014). Di Amerika Serikat, angka kejadian abortus secara nasional berkisar antara 10-20\%. Menurut Depkes RI di Indonesia abortus menempati urutan kedua penyebab AKI yaitu sebanyak 26\%, di Indonesia terdapat 43 kasus abortus per 100 ribu kelahiran hidup. Kejadian abortus di Indonesia paling tinggi di Asia Tenggara, yaitu sebesar dua juta dari 4,2 juta kasus (Rahmani, 2014). Berdasarkan SDKI 2012 Angka Kematian Ibu (AKI) sebesar 359 per 100.000 kelahiran hidup. AKI Indonesia yang mencapai 305 per 100.000 pada tahun 2015, Penyebab langsung kematian ibu tahun 2013 adalah pendarahan 30,3\%, hipertensi 27,1\%, infeksi 7,3\%, partus lama 0\%, abortus 0\%, lain-lain 40,8\%, (Kemenkes RI, 2015). Kejadian abortus di Indonesia setiap tahun terjadi 2 juta kasus. Ini artinya terdapat 43 kasus abortus per 100 kelahiran hidup.

Hampir 50\% dari kehamilan berakhir dengan keguguran, jika kehamilan berlanjut janin yang dilahirkan oleh ibu akan berakibat buruk seperti kelahiran prematur, ketuban pecah dini, preeklamsia, solusio plasenta dan Intrauterine Growth Restriction (IUGR) dapat terjadi. Hal ini juga diketahui bahwa usia ibu, penyakit sistemik seperti diabetes mellitus, hipotiroidisme, pengobatan infertilitas, trombofilia, berat badan ibu dan struktur rahim yang abnormal meningkatkan risiko abortus imminens.

Penyakit-penyakit ibu seperti penyakit infeksi yang menyebabkan demam tinggi karena pneumonia, tifoid, pielitis, rubella, demam malta, dan sebagainya; Kematian fetus dapat disebabkan karena toksin dari ibu atau invasi kuman atau virus pada fetus; Keracunan $\mathrm{Pb}$, nikotin, gas racun, alkohol, dan lain-lain, ibu yang asfeksia seperti pada dekompensasi kordis, penyakit paru berat, anemi gravis; Malnutrisi, avitaminosis dan gangguan metabolisme, hipotiroid, kekurangan vitamin $\mathrm{A}, \mathrm{C}$, atau $\mathrm{E}$, dan diabetes melitus juga merupakan faktor penyebab terjadinya abortus imminens (Yakistiran dkk, 2016).

Rumah Sakit Umum Daerah (RSUD) Kota Padangsidimpuan merupakan salah satu fasilitas kesehatan terbesar di Kota Padangsidimpuan. Rumah Sakit Umum Daerah Kota Padangsidimpuan juga merupakan rumah sakit rujukan dari segala daerah yang berada disekitar Pemerintahan Kota Padangsidimpuan. Kejadian abortus pada tahun 2015-2016 terdapat 192 kasus yang terdiri dari kasus abortus imminens, inkomplitus, komplitus, missed abortion dan insipiens. Dari 192 kasus abortus diatas abortus imminens sebanyak 50 kasus. 


\section{Rumusan Masalah}

Abortus imminens merupakan komplikasi kehamilan tersering dan menyebabkan beban emosional serius. Apabila Abortus Imminens tidak diberi penanganan yang tepat dan sesuai dengan prosedur maka akan terjadi komplikasi yang menyebabkan meningkatnya angka morbiditas ibu. Dan apabila komplikasi tersebut tidak juga diberi penangan yang tepat maka bisa saja terjadi kematian pada ibu yang akan meningkatkan angka mortalitas ibu. Terlalu sedikit informasi yang di dapat oleh ibu baik di praktek umum maupun di fasilitas kesehatan lainnya mengenai alasan mengapa abortus terjadi serta akibatnya pada kehamilan yang akan datang. Berdasarkan latar belakang masalah, maka penulis tertarik untuk menganalisis pengaruh penyakit ibu terhadap kejadian abortus imminens di Rumah Sakit Umum Daerah Kota Padangsidimpuan periode tahun 2015-2016.

\section{METODE PENELITIAN}

Jenis penelitian yang digunakan adalah studi analitik observasional dengan desain penelitian case control. Pada studi case control, penelitian dimulai dengan identifikasi pasien dengan efek atau penyakit tertentu (yang disebut sebagai kasus) dan kelompok tanpa efek (disebut kontrol). Kemudian secara retrospektif ditelusuri faktor risiko yang dapat menerangkan mengapa kasus terkena efek, sedangkan kontrol tidak. Penelitian ini akan menilai hubungan faktor dengan kejadian abortus menggunakan cara penentuan kelompok kasus dan kelompok kontrol, kemudian mengukur besarnya risiko (frekuensi paparan) pada kedua kelompok tersebut.

Penelitian ini dilakukan di Rumah Sakit Umum Daerah Kota Padangsidimpuan dengan menggunakan data rekam medik kasus abortus imminens. Populasi adalah seluruh ibu hamil yang di diagnosa oleh dokter mengalami abortus imminens periode Januari-Desember 2015 dan Januari-Desember 2016.Variabel yang diamati dalam penelitian ini adalah penyakit ibu.

Metode analisis data yang digunakan meliputi analisis univariat untuk menjelaskan atau mendeskripsikan karakteristik variabel penelitian dan analisis bivariat dengan chi-square yaitu dengan melihat dari hasil uji statistik ini akan dapat disimpulkan adanya pengaruh variabel tersebut bermakna atau tidak bermakna. Waktu penelitian ini dimulai dari bulan Maret s/d Juli 2017. 


\section{HASIL DAN PEMBAHASAN}

Tabel 1. Karakteristik Ibu Hamil Dengan Abortus Imminens di Rumah Sakit Umum Daerah Kota Padangsidimpuan

\begin{tabular}{|c|c|c|c|c|c|}
\hline \multirow[t]{2}{*}{ No } & \multirow[t]{2}{*}{ Karakteristik } & \multicolumn{2}{|c|}{ Kasus } & \multicolumn{2}{|c|}{ Kontrol } \\
\hline & & $(\mathbf{n}=\mathbf{5 0})$ & $(\%)$ & $(n=50)$ & $(\%)$ \\
\hline \multicolumn{6}{|c|}{ Umur Ibu } \\
\hline 1. & $<20$ dan $>35$ tahun & 38 & 76,0 & 20 & 40,0 \\
\hline 2. & 20-35 tahun & 12 & 24,0 & 30 & 60,0 \\
\hline \multicolumn{6}{|c|}{ Usia Kehamilan } \\
\hline 1. & $<20$ minggu & 30 & 60,0 & 14 & 22,0 \\
\hline 2. & $>20$ minggu & 20 & 40,0 & 36 & 72,0 \\
\hline \multicolumn{6}{|c|}{ Paritas } \\
\hline 1. & $<1$ dan $\geq 4$ & 37 & 74,0 & 17 & 34,0 \\
\hline 2. & $1-3$ & 13 & 26,0 & 33 & 66,0 \\
\hline \multicolumn{6}{|c|}{ Riwayat Abortus } \\
\hline 1. & $\begin{array}{l}\text { Ada } \\
-1 \mathrm{Kali} \\
-2 \mathrm{Kali} \\
-\geq 3 \mathrm{Kali}\end{array}$ & 37 & 74,0 & 8 & 16,0 \\
\hline 2. & Tidak Ada & 13 & 26,0 & 42 & 84,0 \\
\hline \multicolumn{6}{|c|}{ Penyakit Ibu } \\
\hline 1. & $\begin{array}{l}\text { Ada } \\
\text { - Hipertensi } \\
\text { - Diabetes Mellitus } \\
\text { - Anemia } \\
\text { - Dll (Tifus, Demam } \\
\text { berdarah, Asma, } \\
\text { Hepatitis, Hiperemesis } \\
\text { Gravidarum) }\end{array}$ & 39 & 78,0 & 6 & 12,0 \\
\hline 2. & $\begin{array}{l}\text { Tidak Ada } \\
\text { Jumlah }\end{array}$ & $\begin{array}{l}11 \\
\mathbf{5 0}\end{array}$ & $\begin{array}{c}22,0 \\
100,0\end{array}$ & $\begin{array}{l}44 \\
\mathbf{5 0}\end{array}$ & $\begin{array}{c}88,0 \\
100,0\end{array}$ \\
\hline
\end{tabular}

Berdasarkan Tabel 1 pada kelompok kasus diketahui paling banyak $<20$ tahun dan $>35$ tahun yaitu 38 orang (76\%), usia kehamilan kurang dari 20 minggu sebanyak 30 orang (60\%), Paritas $<1$ dan $\geq 4$ yaitu sebanyak 37 orang (74\%). Ibu dengan adanya riwayat abortus sebanyak 37 orang (74\%) dengan riwayat abortus 1 kali sebanyak 17 orang, riwayat abortus 2 kali sebanyak 11 orang, dan riwayat abortus $\geq 3$ sebanyak 9 orang. Ibu dengan adanya riwayat penyakit sebanyak 39 orang $(78 \%)$ dengan penyakit anemia sebanyak 7 orang, penyakit diabetes mellitus sebanyak 9 orang, penyakit hipertensi sebanyak 11 orang, dan penyakit lainnya seperti tifus, demam berdarah, hepatitis, asma, hiperemesis gravidarum sebanyak 12 orang. 
Tabel 2. Pengaruh Penyakit Ibu Terhadap Kejadian Abortus Imminens di Rumah Sakit Umum Daerah Kota Padangsidimpuan

\begin{tabular}{|c|c|c|c|c|c|c|}
\hline \multirow{3}{*}{ Penyakit Ibu } & \multicolumn{4}{|c|}{$\begin{array}{c}\text { Kejadian Abortus } \\
\text { Immines } \\
\end{array}$} & \multirow{3}{*}{$\begin{array}{c}\text { OR } \\
(95 \% \mathrm{CI})\end{array}$} & \multirow{2}{*}{$\begin{array}{l}\chi^{2} / P \\
\text { value }\end{array}$} \\
\hline & \multicolumn{2}{|c|}{ Positif } & \multicolumn{2}{|c|}{ Negatif } & & \\
\hline & $\mathbf{n}$ & $\%$ & $\mathbf{n}$ & $\%$ & & \\
\hline Ada & 39 & 78,0 & 6 & 12,0 & 26,0 & $41,374 /$ \\
\hline Tidak ada & 11 & 22,0 & 44 & 88,0 & $(8,79-76,8)$ & 0,0001 \\
\hline Total & 50 & 100,0 & 50 & 100,0 & & \\
\hline
\end{tabular}

Hasil analisis statistik dengan uji chi-square diperoleh nilai $p<0,05$ nilai $\chi^{2}$ hitung $=41,374$ dengan nilai $p$ (value) $=0,0001$ pada $\alpha=0,05$. Karena nilai $p$ (value) $0,0001<0,05$ yang berarti menunjukan ada pengaruh penyakit ibu terhadap kejadian abortus imminens. Nilai Odds Ratio diketahui sebesar 26,0, ini berarti bahwa ibu pada kelompok kasus berisiko mengalami kejadian abortus imminens sebesar 26 kali lebih tinggi dibandingkan dengan ibu pada kelompok kontrol.

Ibu yang mempunyai penyakit maka fisiknya tidak akan siap dalam menghadapi kehamilan. Penyakit yang diserita ibu hamil akan memperburuk risiko janin yang dikandungnya, sebab kondisi janin akan bergantung pada kondisi kesehatan ibu. Selain itu ibu yang mengalami kelainan plasenta, misalnya endarteritis terjadi dalam vili koriales dan menyebabkan oksigenasi plasenta terganggu, sehingga mengganggu pertumbuhan dan kematian janin. Penyakit ibu dapat secara langsung memengaruhi pertumbuhan janin dalam kandungan melalui plasenta. Penyakit infeksi seperti pneumonia, tifus abdominalis, malaria, dan sifilis. Anemia ibu melalui gangguan nutrisi dan peredaran $\mathrm{O}_{2}$ menuju sirkulasi retroplasenta. Dan penyakit menahun seperti hipertensi, penyakit ginjal, penyakit hati, dan penyakit diabetes mellitus.

Penyakit-penyakit ibu yaitu penyakit infeksi yang menyebabkan demam tinggi karena pneumonia, tifoid, pielitis, rubella, demam malta, dan sebagainya; Kematian fetus dapat disebabkan karena toksin dari ibu atau invasi kuman atau virus pada fetus; Keracunan $\mathrm{Pb}$, nikotin, gas racun, alkohol, dan lain-lain, ibu yang asfeksia seperti pada dekompensasi kordis, penyakit paru berat, anemi gravis; Malnutrisi, avitaminosis dan gangguan metabolisme, hipotiroid, kekurangan vitamin $\mathrm{A}, \mathrm{C}$, atau $\mathrm{E}$, dan diabetes melitus juga merupakan faktor penyebab terjadinya abortus imminens.

Menurut Wiknjosastro (2010), bahwa wanita yang hamil pada umur muda ( $<20$ tahun) dari segi biologis perkembangan alat-alat reproduksinya belum sepenuhnya optimal.dari segi psikis belum matang dalam menghadapi tuntutan beban moril, dan emosional, dan dari segi medis sering mendapat gangguan, sedangkan pada usia lebih dari 35 tahun, elastic dari otot-otot panggul dan sekitarnya serta alat-alat reproduksinya mengalami kemunduran, juga wanita pada usia ini besar kemungkinan mengalami komplikasi antenatal diantaranya abortus. Pada usia kehamilan kurang dari 8 minggu villi koriales belum menembus desidua secara mendalam sehingga pada umumnya perdarahan tidak terlalu banyak. Pada kehamilan antara 8-14 minggu villi koriales menembus desidua lebih dalam, sehingga umumnya dapat menyebabkan banyak perdarahan. Abortus imminens juga terjadi dapat pada usia kehamilan risiko rendah karena pada dasarnya setiap ibu hamil mempunyai risiko untuk terjadi abortus imminens, bila tidak ditangani dan dicegah dengan asuhan kebidanan yang lebih baik. 
Risiko abortus imminens semakin tinggi dengan bertambahnya paritas dan semakin bertambahnya usia ibu dengan asumsi bahwa semakin tinggi paritas maka semakin tinggi angka kejadian abortus dan semakin rendah paritas maka angka kejadian abortus akan semakin rendah. Komplikasi yang berbahaya pada abortus ialah perdarahan, perforasi, infeksi dan syok.

Ibu dengan riwayat sudah pernah mengalami abortus dua kali berturut-turut maka kehamilan berikutnya hanya $63 \%$ berjalan normal, tetapi kehamilan keempat berjalan normal hanya sekitar 16\% (Mochtar, 2011). Menurut pendapat Danvers (2010), semakin tinggi riwayat abortus, semakin besar pula risiko terjadinya abortus. Penelitian Maconochie dkk (2011) juga menunjukkan bahwa terdapat hubungan yang bermakna antara riwayat abortus dengan kejadian abortus. Prawirohardjo (2014) mengemukakan bahwa wanita yang telah mengalami keguguran 2 kali bahkan sampai 3 kali berturut-turut, mempunyai kemungkinan untuk kembali keguguran menjadi lebih besar. Menurut Malpas dan Eastman kemungkinan terjadinya abortus lagi pada seorang wanita ialah $73 \%$ dan $83,6 \%$. Sedangkan, Warton dan Fraser dan Llewellyn Jones memberi prognosis yang lebih baik, yaitu 25,9\% dan 39\% (Wiknjosastro, 2010). Kejadian abortus diduga mempunyai efek terhadap kehamilan berikutnya, baik pada timbulnya penyulit kehamilan maupun pada hasil kehamilan itu sendiri. Wanita dengan riwayat abortus mempunyai risiko lebih tinggi untuk persalinan prematur, abortus berulang dan bayi dengan berat badan lahir rendah (Cunningham, 2014).

Hampir 50\% dari kehamilan berakhir dengan keguguran, jika kehamilan berlanjut janin yang dilahirkan oleh ibu akan berakibat buruk seperti kelahiran prematur, ketuban pecah dini, preeklamsia, solusio plasenta dan Intrauterine Growth Restriction (IUGR) dapat terjadi. Hal ini juga diketahui bahwa usia ibu, penyakit sistemik seperti diabetes mellitus, hipotiroidisme, pengobatan infertilitas, trombofilia, berat badan ibu dan struktur rahim yang abnormal meningkatkan risiko abortus imminens. Ibu yang menderita penyakit seperti pneumonia, tifus abdominalis, pielonefritis, malaria, dan lain-lain, maupun kronik seperti, anemia berat, keracunan, laparotomi, peritonitis umum, dan penyakit menahun seperti brusellosis, mononukleosis infeksiosa, toksoplasmosis, kemunginan akan mengalami abortus. Ibu yang mempunyai penyakit kemungkinan akan mengalami beberapa risiko yang menyebabkan abortus, kelahiran prematur, bayi dengan berat badan lahir yang rendah, pendarahan antepartum, ketuban pecah dini hingga keguguran atau kematian janin.Karena itu, jika setelah abortus imminens ini kehamilan masih dilanjutkan, pemeriksaan rutin, istirahat yang cukup serta makanan bernutrisi tinggi menjadi kebutuhan yang harus dipenuhi (Triana, 2015).

Seorang perempuan hamil harus menjaga asupan gizinya dengan makan makanan yang bergizi tinggi dengan diet seimbang dan selalu menjaga berat badan ibu sehingga terkontrol dan tidak mengalami tekananan darah tinggi. Seorang perempuan hamil juga sebaiknya tetap melakukan olahraga ringan yang sangat bermanfaat bagi ibu dan bayi seperti berenang dan berjalan kaki. Perbanyaklah pengetahuan mengenai kehamilan dan risiko kehamilan tinggi sehingga dapat mencegah hal-hal yang tidak diinginkan (Lubis, 2017).

\section{KESIMPULAN DAN SARAN}

Berdasarkan hasil analisis statistik dengan uji chi-square diperoleh nilai $p$ (value) $0,0001<0,05$ yang berarti menunjukan ada pengaruh penyakit ibu terhadap kejadian abortus imminens. Nilai Odds Ratio diketahui sebesar 26,0 yang berarti bahwa ibu pada kelompok kasus berisiko mengalami kejadian abortus imminens sebesar 26 kali lebih tinggi dibandingkan dengan ibu pada kelompok kontrol. 
Adapun saran-saran kepada ibu hamil dengan atau tanpa risiko tinggi sebaiknya memelihara kesehatan agar tidak sakit, melakukan kontrol kehamilan secara teratur baik itu kepada bidan maupun kepada dokter kandungan dan pemeriksaan secara teratur setiap bulan dapat mencegah hal-hal yang membahayakan bagi ibu dan bayi.

Bagi petugas kesehatan khususnya bidan diharapkan agar lebih meningkatkan ilmu dan keterampilan agar dapat mendeteksi sedini mungkin terjadinya abortus imminens sehingga komplikasi dapat diatasi dengan baik dan dapat memberikan penyuluhan atau konseling kepada ibu hamil mengenai abortus imminens.

\section{Ucapan Terimakasih}

Penulis mengucapkan terimakasih kepada Prof. Dr. Dra. Ida Yustina, M.Si selaku Dekan Fakultas Kesehatan Masyarakat Universitas Sumatera Utara, Ir Etti Sudaryati, M.K.M, Ph.D selaku Ketua Program Studi S2 Fakultas Kesehatan Masyarakat Universitas Sumatera Utara, Sri Rahayu Sanusi, S.K.M, M.Kes, Ph.D dan Prof. dr. Delfi Lutan, Sp.OG (K) selaku dosen pembimbing yang telah membimbing dan mengarahkan penulis hingga penelitian ini selesai dan kepada Direktur Rumah Sakit Umum Daerah Kota Padangsidimpuan yang telah memberikan dukungan terhadap penelitian ini.

\section{REFERENSI}

Arikunto, Suharsimi. 2016. Prosedur Penelitian: Suatu Pendekatan Praktik. Jakarta : Rineka Cipta

Cunningham, F. Gary. 2014. Williams Obstetrics 24th Edition. United States: McGraw-Hill Education.

Hamidah. 2013. Faktor Dominan yang Berhubungan Dengan Kejadian Abortus Imminens. Jurnal Ilmu \& Teknologi Ilmu Kesehatan, Jilid 1, Nomor 1, September 2013 : 29-33.

Ilhaini, Nur. 2013. Abortus Imminens: Upaya Pencegahan, Pemeriksaan, dan Penatalaksanaan. Majalah Cermin Dunia Kedokteran CDK-206/ vol. 40 no. 7 : 492-496

Kurniawan, Arif. 2016. Early Detection Of High Risk Pregnancy. Jurnal KEMAS, 12 (2) : $96-$ 103.

Lubis, Zulhaida. 2017. Karakteristik, Asupan Gizi dan Kejadian Anemia pada Ibu Hamil. Jurnal Media Kesehatan Masyarakat Indonesia FKM UNHAS, 13 (3): 224-229

Lemeshow, Stanley., Hosmer, D.W., Klar, J., Lwanga, S.K. 1997. Besar Sampel Dalam Penelitian Kesehatan. Yogyakarta: Gadjah Mada University Press

Manuaba, Ida Bagus Gde., Manuaba Ida Bagus Gde Fajar., Manuaba Ida Ayu Chandranita. 2013. Ilmu Kebidanan Penyakit Kandungan Dan KB Untuk Pendidikan Bidan. Jakarta: ECG

Mochtar, Rustam. 2011. Sinopsis Obstetri: Obstetri Fisiologi, Obstetri Patologi. Jakarta: EGC

Notoatmodjo, Soekidjo. 2016. Metodologi Penelitian Kesehatan. Jakarta : Rineka Cipta

Prawirohardjo, Sarwono. 2014. Ilmu Kebidanan. Jakarta: Bina Pustaka Sarwono Prawirohardjo.

Rahmani, Silmi Lisani. 2014. Faktor-Faktor Risiko Kejadian Abortus Di RS Prikasih Jakarta Selatan Pada tahun 2013. Skripsi Publikasi. Universitas Islam Negeri Syarif Hidayatullah Jakarta Fakultas Kedokteran Dan Ilmu Kedokteran.

Studnicki, James., J. MacKinnon, Sharon., W. Fisher, John. 2016. Induced Abortion, Mortality, and the Conduct of Science. Scientific Research Publishing, Open Journal of Preventive Medicine, 2016, 6, 170-177. Diakses 23 Maret 2017; http://dx.doi.org/10.4236/ojpm.2016.66016 
Survey Demografi Dan Kesehatan Indonesia (SDKI) 2012. 2013. Jakarta: Badan Pusat Statistik Wadud, Mursyida. 2012. Faktor-Faktor Yang Berhubungan Dengan Kejadian Abortus Imminens Di Instalasi Rawat Inap Kebidanan Rumah Sakit Muhammadiyah Palembang Tahun 2011. Poltekkes Kemenkes Palembang Jurusan Kebidanan. Diakses 13 Februari 2017; www.poltekkespalembang.ac.id

Rukiyah, Yeyeh Ai., Yulianti, Lia. 2010. Asuhan Kebidanan 4 (Patologi Kebidanan). Jakarta : Trans Info Medika

Yakıştıran, Betül., Yüce ,Tuncay., Söylemez, Feride. 2016. First Trimester Bleeding and Pregnancy Outcomes: Case-Control Study. International Journal of Women's Health and Reproduction Sciences IJWHR Vol. 4, No. 1, January 2016, 4-7. Diakses 22 Maret 2017; http://www.ijwhr.net 